\title{
Pengaruh Leverage, Profitabilitas, Ukuran Perusahaan, Dan Likuiditas Terhadap Tax Avoidance
}

\author{
Deti Astrit Oktaviani ${ }^{1}$, Mohamad ZulmanHakim², Dirvi Surya Abbas ${ }^{3}$ \\ Univeritas Muhammadiyah Tangerang \\ e-mail : detiastritoktaviani03@gmail.com ${ }^{1}, \underline{\text { zulman.hakim@umt.ac.id }}$, \\ abbas.dirvi@gmail.com ${ }^{3}$
}

\begin{abstract}
Abstrak: Tujuan dari penelitian ini untuk mengetahui pengaruh leverage (DER), Profitabilitas (ROA), Ukuran perusahaan (SIZE), dan Likuiditas (CR) terhadap Tax Avoidance. Dengan variable dependen tax avoidance yang di proksikann kepada CETR (Cash Effective Tax Rate). Populasi dalam penelitian ini meliputi seluruh perusahaan Food and Beverage yang terdaftar di Bursa Efek Indonesia (BEI) pada tahun 2017 2019 yang berjumlah 24 perusahaan dengan menggunakan purposive sampling diperoleh 17 perusahaan yang memenuhi kriteria, dengan jumlah data observasi sebanyak 51 data. Penelitian ini menggunakan analisis regresi data panel dengan bantuan program Eviews 9 . Hasil penelitian ini menunjukkan bahwa secara secara simultan variabel DAR, ROA,SIZE , dan CR berpengaruh terhadap CETR. Sedangkan secara parsial variabel SIZE, dan CR tidak berpengaruh terhadap CETR, sedangkan DAR dan ROA berpengaruh terhadap CETR.
\end{abstract}

Kata Kunci : Leverage, Profitabilitas, Ukuran Perusahaan, Likuiditas

Pajak merupakan sumber pendapatan terbesar bagi negara, yang digunakan untuk membiayai pengeluaran negara, baik pengeluaran rutin maupun pengeluaran pembangunan nasional. Berdasarkan Pasal 37A Ayat (1) UU No.28 Tahun 2007 tentang ketentuan Umum dan Tata Cara Perpajakan, Pajak merupakan "kontribusi wajib kepada negara yang terutang oleh orang pribadi atau badan yang bersifat memaksa berdasarkan Undang-undang, dengan tidak mendapat timbal balik secara langsung dan digunakan untuk keperluan negara bagi sebesar-besarnya kemakmuran rakyat". Perbedaan kepentingan negara yang menginginkan penerimaan pajak yang besar dan berkelanjutan bertolak belakang dengan kepentingan perusahaan yang menginginkan pembayaran pajak seminimal mungkin. Perbedaan dengan kepentingan bagi negara dan bagi perusahaan akan menimbulkan ketidakpatuhan yang dilakukan oleh wajib pajak perusahaan yang akan berdampak bagi upaya perusahaan untuk melakukan Penghindaran Pajak (tax avoidance).

Terdapat fenomena penghindaran pajak yang dilakukan oleh perusahaan-perusahaan yang bergerak di sektor Food and Beverage yang menjalankan bisnisnya di Indonesia.PT Cocacola Indonesia diduga mengakali pajak sehingga menimbulkan kekurangan pembayaran pajak senilai Rp. 49,24 miliar. Hasil penelusuran Direktorat

Jenderal Pajak (DJP) Kementerian Keuangan menemukan adanya pembengkakan biaya yang besar pada tahun 2002, 2003, 2004, dan 2006. Beban biaya yang besar menyebabkan penghasilan kena pajak berkurang, sehingga setoran pajaknya pun mengecil. Beban biaya itu antara lain untuk iklan dari rentang waktu tahun 2002-2006 dengan total 
sebesar Rp. 566,84 miliar. Itu untuk iklan produk minuman jadi merk Cocacola akibatnya ada penurunan penghasilan kena pajak. Menurut DJB, total penghasilan kena pajak CCl pada periode itu adalah Rp. 603,48 miliar. Sedangkan perhitungan $\mathrm{CCl}$, penghasilan kena pajak hanyalah Rp.492,59 miliar. Dengan selisih itu, DJP menghitung kekurangan pajak penghasilan (PPh) CCI Rp. 49,24 miliar (www.kontan.co.id uni 2014).

Terdapat bebebrapa faktor yang mempengaruhi perusahaan dalam membayar beban pajaknya kepada negara. Penelitian terdahulu menyebutkan dalam melakukan penghindaran pajak beberapa faktor yang mempengruhinya yaitu ukuran perusahaan, profitabilitas, leverage, komite audit, kepemilikan institusional, karaktersitik eksekutif, CSR. faktor tersebut memotivasi peneliti untuk melakukan penelitian kali ini dengan faktor yang diambil adalah leverage, profitabilitas, ukuran perusahaan, dan likuiditas.

Menurut Harcriswono, 2008 penghindaran pajak (tax avoidance) adalah sebuah perencanaan berupa rekayasa dalam urusan perpajakan tetapi masih dalam ranah ketentuan perpajakan untuk menekan beban pajak serendah mungkin. Pajak (tax avoidance) merupakan upaya penghindaran pajak yang memiliki dampak terhadap kewajiban pajak yang dilakukan dengan cara masih tetap dalam ketentuan perpajakan tidak melanggar ketentuan perpajakan yang telah ditetapkan. Tekniknya dilakukan dengan memanfaatkan kelemahan-kelemahan dalam Undangundang dan peraturan perpajakan untuk memperkecil jumlah pajak yang terutang sehingga melakukan transaksi yang tidak dibebankan dengan beban pajak.

Utang perusahaan merupakan sesuatu yang ada ketika perusahaan menggunakannya untuk memenuhi kebutuhan oprasional dan investasi perusahaan. Kasmir (2010) dalam teguh (2015) menyebtukan bahwa leverage dapat dihitung dengan menggunakan rasio yang yamengukur sejauh mana aset perusahaan yang dibiayai dengan utang. artinya,perusahan demgam beban utang yang ditanggung dibandingkan asetnya. Utang akan menimbulkan beban tetap (fixed rate of return) yang disebut beban bunga. Beban bunga yang ditanggung perusahaan akan dapat mengurangi penghasilan kena pajak yang harus dibayar perusahaan pada negara. Semakin tinggi beban bunga akan memberikan pengaruh berkurangnya beban pajak perusahaan.

Profitabilitas merupakan kemampuan sebuah perusahaan dalam menghasilkan laba dalam periode tertentu pada tingkat penjualan, asset, dan modal saham tertentu. Penghindaran pajak terjadi pada saat perusahaan mengurangi laba yang didapat. Untuk mengurangi beban pajak yang harus dibayar atau tax avoidance. Perusahaan yang mempunyai tingkat profitabilitas yang tinggi cenderung ingin segera mempublikasikannya karna akan memepertinggi nilai perusahaan dimata pihak yang berkepentingan ( Hakim, 2018).

Perusahaan merupakan wajib pajak, sehingga ukuran perusahaan dianggap mampu mempengaruhi cara sebuah perusahaan dalam 
memenuhi kewajiban pajaknya dan merupakan faktor yang dapat menyebabkan terjadinya tax avoidance. Machfoedz (1994) dalam Puttu Erry (2016) menyatakan bahwa ukuran perusahaan merupakan suatu skala yang dapat mengelompokkan perusahaan menjadi perusahaan besar dan kecil menurut berbagai cara seperti contoh, ukuran perusahaan bisa kita lihat melalui total aset perusahaan yang dimiliki, nilai pasar saham, rata-rata tingkat penjualan, dan jumlah penjualan. Ukuran perusahaan ditunjukkan melalui log total aset, karena dinilai bahwa ukuran ini memiliki tingkat kestabilan yang lebih dibandingkan proksi-proksi yang lainnya dan berkesinambungan antar periode (Yogiyanto 2007:282).

Subramanyam dan Wild (2010:241) mendefinisikan likuidias sebagai kemampuan perusahaan untuk memenuhi kewajiban jangka pendeknya yang secara konvensional, 'jangka pendek' dianggap periode hingga satu tahun meskipun dikaitkan dengan siklus operasional normal perusahaan. Dengan demikian likuiditas sangat penting bagi sebuah perusahaan. Likuiditas dapat digunakan untuk memperhitungkan dampak yang berasal dari ketidakmampuan perusahaan memenuhi kewajiban jangka pendeknya. Dalam kaitannya dengan pajak, Suyanto dan Supramono (2010) menyatakan bahwa likuiditas sebuah perusahaan diprediksi akan mempengaruhi agresivitas pajak perusahaan. Perusahaan yang memiliki likuiditas tinggi menggambarkan arus kas yang baik sehingga perusahaan tersbut tidak enggan untuk membayar seluruh kewajibannya termasuk membayar pajak sesuai peraturan yang berlaku. Senada dengan hal tersebut Bradley dan Siahaan (dalam Suyanto dan Supramono, 2010) yang menemukan bahwa perusahaan yang memiliki arus kas yang rendah akan tidak taat terhadap pajak guna mempertahankan arus kas perusahaan dari pada harus membayar pajak.

\section{METODE}

Metode penelitian sampel yang digunakan adalah Puposive Sampling, yaitu tipe pemilihan sampel berdasarkan pertimbangan - pertimbangan tertentu (Sugiyono, 2010:122), yang diambil berdasarkan tujuan penelitian. Sampel dalam penelitian ini adalah Sub Sektor food and beverage yang terdaftar di Bursa Efek Indonesia (BEI) selama tahun 2017-2019. Dari hasil pemilihan sample yang dipilih, diambil sample perusahaan dengan 17 perusahaanyang memenuhi kriteria penelitian dengan total penelitian 51 .

Metode pengumpulan data yang digunakan didalam penelitian ini adalah studi dokumentasi dengan memperoleh data berupa laporan tahunan yang telah dikeluarkan oleh perusahaan pada periode semakin tinggi nilai CETR, maka semakin kecil usaha dalam mengindari pajak, begitu pula sebaliknya semakin kecil nilai CETR maka semakin besar praktik penghindaran pajak yang dapat dilakukan perusahaan.

Untuk menghitung profitabilitas dapat dilakukan dengan menggunakan penghitungan ROA (return on asset), rasio ini membandingkan laba bersih setalah pajak dengan seluruh asset. Laba 
Bersih Sebelum Pajak tahun 2017-2019. Data tersebut diperoleh melalui situs yang dimiliki BEI, yaitu www.idx.co.id dan website perusahaan. Total Aset dibagi laba sebelum pajak (Budiman, 2012)

Pengukuran perusahaan diukur berdasarkan total asset yang dimiliki perusahaan. Dengan rumus yang digunakan

SIZE = Ln ( total asset)

Tax avoidance adalah usaha perusahaan dalam upaya mengurangi serta menghindari beban pajak yang harus dibayar perusahaan terhadap negara, dalam penelitian ini pengukuran yang digunakan dalam menghitung Tax avoidance adalah effective tax rates (CETR) perusahaan yaitu kas yang dikeluarkan untuk biaya pajak

Debt to Equity Ratio atau DER merupakan ukuran kemampuan perusahaan untuk melunasi kewajibannya. Dengan demikian, perusahaan yang memiliki Debt to Equity Ratio atau Rasio Hutang terhadap Ekuitas yang tinggi mungkin tidak dapat menarik tambahan modal dengan pinjaman dari pihak lain.. Leverage dapat diukur dengan rumus sebagai berikut: Total Hutang dibagi Total Ekuitas

Likuiditas merupakan kemampuan pada suatu perusahaan didalam memenuhi seluruh kewajiban keuangan yang secepatnya dapat dicairkan atau yang sudah jatuh tempo. Secara spesifik likuiditas tersebut mencerminkan ketersedian dana yang dipunyai perusahaan guna memenuhi seluruh hutang yang akan jatuh tempo (Syafrida hani (2015:121).). Kepemilikan instistusional (KEI) dapat dihitung dengan rasio: Aset Lancar dibagi Kewajiban Lancar

\section{HASIL}

Hasil Analisis Statistik Deskriptif Anaslisis statistik deskriptif pada table hasil, dapat dijelaskan bahwa jumlah data (observations) yang digunakan dalam penelitian ini adalah sebanyak 51 data.

\begin{tabular}{|c|c|c|c|c|c|}
\hline & TAV & DAR & ROE & SIZE & $C R$ \\
\hline Mean & 0.297451 & 0.390196 & 0.131961 & 25.41294 & 3.157059 \\
\hline Median & 0.260000 & 0.370000 & 0.120000 & 27.36000 & 2.260000 \\
\hline Maximum & 1.570000 & 0.910000 & 0.300000 & 30.58000 & 15.82000 \\
\hline Minimum & 0.040000 & 0.120000 & 0.000000 & 15.46000 & 0.490000 \\
\hline Std. Dev. & 0.222026 & 0.189309 & 0.072637 & 4.397892 & 3.137496 \\
\hline Skewness & 4.424966 & 0.595167 & 0.116367 & -1.128575 & 2.290258 \\
\hline Kurtosis & 24.27480 & 2.998373 & 2.312306 & 2.900991 & 8.304322 \\
\hline Jarque-Bera & 1128.244 & 3.010905 & 1.120063 & 10.84712 & 104.3735 \\
\hline Probability & 0.000000 & 0.221917 & 0.571191 & 0.004411 & 0.000000 \\
\hline Sum & 15.17000 & 19.90000 & 6.730000 & 1296.060 & 161.0100 \\
\hline Sum Sq. Dev. & 2.464769 & 1.791898 & 0.263804 & 967.0729 & 492.1941 \\
\hline Observations & 51 & 51 & 51 & 51 & 51 \\
\hline
\end{tabular}

Tax avoidance sebagai variable dependen (y) memiliki nilai terendah 0.040000 dan nilai tertinggi 1.570000 dengan rata-rata 0.297451 dengan standar devisiasi 0.222026. nilai mean sebesar 0.297451 (29.74\%) menunjukan bahwa rata-rata tax avoidance perusahaan sample yang diteliti adalah 29.74\%. standar deviasi $22,20 \%$ menunjukan bahwa tax 
avoidance dari perusahaan-perusahaan sampel yang diteliti memiliki perbedaan yang relative kecil.

Leverage (X1) memiliki nilai terendah 0.120000 dan nilai tertinggi 0.910000 dengan rata-rata 0.390196 dengan standar deviasi 0.189309 . nilai mean 0.437917 (43.79\%) menunjukan bahwa rata-rata leverage sample yang diteliti adalah $43.79 \%$. standar deviasi $18.93 \%$ menunjukan bahwa leverage dari perusahaan-perusahaan yang dijadikan sampel penelitian memiliki perbedaan yang relative besar.

Profitabilitas (X2) memiliki nilai terendah 0.000000 dan nilai tertinggi 0.300000 dengan rata-rata 0.131961 dengan standar deviasi 0.072637 . nilai mean $0.131961(13.20 \%)$ menunjukan bahwa rata-rata profitabilitas sample yang diteliti adalah $13.20 \%$. standar deviasi $07.26 \%$ menunjukan bahwa profitabilitas dari perusahaan-perusahaan yang dijadikan sampel penelitian memiliki perbedaan yang relative kecil.

Ukuran perusahaan (X1) memiliki nilai terendah 15.46000 dan nilai tertinggi 30.58000 dengan rata-rata 25.41294 dengan standar deviasi 4.397892. nilai mean 25.41294 (25.41\%) menunjukan bahwa rata-rata ukuran perusahaan sample yang diteliti adalah $25.41 \%$. standar deviasi 43.97\% menunjukan bahwa ukuran perusahaan dari perusahaanperusahaan yang dijadikan sampel penelitian memiliki perbedaan yang relative besar.

Likuiditas (X4) memiliki nilai terendah 0.490000 dan nilai tertinggi 15.82000 dengan rata-rata 3.157059 dengan standar devisiasi 0.166059. nilai mean 3.157059 (31.57\%) menunjukan bahwa rata-rata kepemilikan institusional sample yang diteliti adalah $31.57 \%$. standar deviasi $16.60 \%$ menunjukan bahwa kepemilika institusional dari perusahaan-perusahaan yang dijadikan sampel penelitian memiliki perbedaan yang relative besar.

Nilai minimum paling kecil dari keseluruhan variabel sebesar 0.0000 terletak pada profitabilitas, sedangkan nilai maksimum paling besar dari seluruh variabel sebesar 30.58 yang terletak pada variabel Ukuran perusahaan, nilai rata-rata paling besar 43.79 terletak pada variabel leverage, sedangkan nilai rata-rata yang paling rendah sebesar 13.20 yang terletak pada variabel profitabilitas, standar deviasi paling besar 43.97 terletak pada variabel ukuran perusahaan, sedangkan standar deviasi yang paling kecil sebesar 18.93 terletak pada variabel leverage.

Common effect model merupakan pendekatan model panel yang paling sederhana, karna hanya mengkombinasikan data time series dengan cross section ( Basuki dan Prawoto ;2016). 


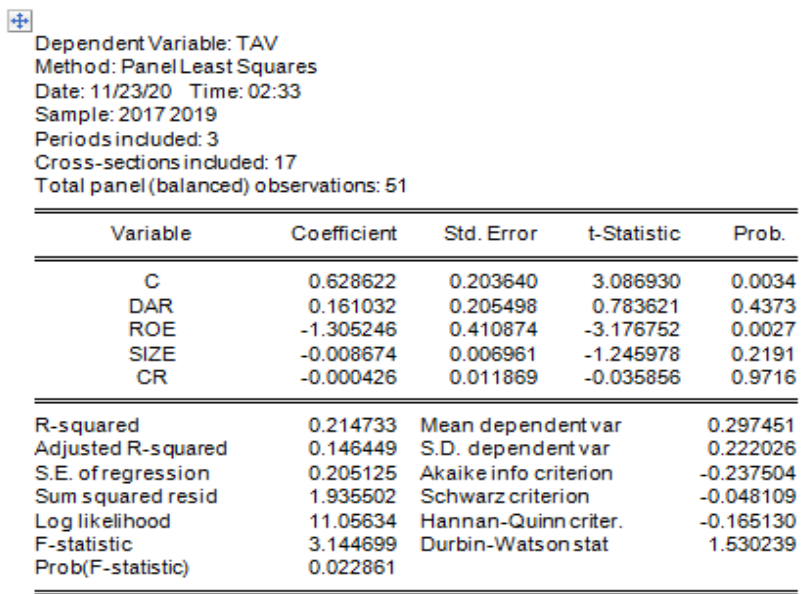

Fixed effect model mengasumsikan bahwa perbedaan anatar individu dapat diakomodasi dari perbedaan intersepnya. Untuk mengestimasi data panel model fixed effects dapat menggunakan variabel dummy untuk menangkap perbedaan intersep antar perusahaan. Berikut adalah bentuk panel fixed effect model :

\begin{tabular}{|c|c|c|c|c|}
\hline \multicolumn{5}{|c|}{$\begin{array}{l}\text { Dependent Variable: TAV } \\
\text { Method: Panel Least Squares } \\
\text { Date: } 11 / 23 / 20 \text { Time: } 02: 34 \\
\text { Sample: } 20172019 \\
\text { Periods included: } 3 \\
\text { Cross-sections included: } 17 \\
\text { Total panel (balanced) observations: } 51\end{array}$} \\
\hline Variable & Coefficient & Std. Error & t-Statistic & Prob. \\
\hline c & -4.013587 & 5.553648 & -0.722694 & 0.4755 \\
\hline DAR & 0.931787 & 0.362850 & 2.567969 & 0.0155 \\
\hline ROE & -2.489526 & 0.840609 & -2.961573 & 0.0059 \\
\hline SIZE & 0.170773 & 0.215761 & 0.791488 & 0.4349 \\
\hline $\mathrm{CR}$ & -0.020227 & 0.039875 & -0.507250 & 0.6157 \\
\hline \multicolumn{5}{|c|}{ Effects Specification } \\
\hline \multicolumn{5}{|c|}{ Cross-section fixed (dummyvariables) } \\
\hline R-squared & 0.522964 & \multirow{6}{*}{\multicolumn{2}{|c|}{$\begin{array}{l}\text { Mean dependent var } \\
\text { S.D. dependent var } \\
\text { Akaike info criterion } \\
\text { Schwarz criterion } \\
\text { Hannan-Quinn criter. } \\
\text { Durbin-Watson stat }\end{array}$}} & 0.297451 \\
\hline Adjusted R-squared & 0.204940 & & & 0.222026 \\
\hline S.E. of regression & 0.197972 & & & -0.108485 \\
\hline Sum squared resid & 1.175783 & & & 0.686972 \\
\hline Log likelihood & 23.76637 & & & 0.195483 \\
\hline F-statistic & 1.644419 & & & 2.047398 \\
\hline Prob(F-statistic) & 0.106122 & & & \\
\hline
\end{tabular}

sumber : olah data eviews 0.9, 2020

Rondom Effect Modeakan mengestimasi data panel dari variabel gangguan yang saling berhubungan antar individu dan antar waktu. Dengan ini setiap perbedaan intersepakan diakomodasi oleh error terms oleh perusahaan. Keuntungan menggunakan model Random Effect yakni menghilangkan heteroskedastisitas. Model ini juga disebut teknik Generalized Least Square (GLS) (Basuki dan Prawoto;2016). berikut adalah bentuk panel model rondom effect model : 


\begin{tabular}{|c|c|c|c|c|}
\hline \multicolumn{5}{|c|}{  } \\
\hline Varlable & Coettclent & std. Error & i-statstc & Prob. \\
\hline$c$ & 0.628622 & 0.196538 & 3.198456 & 0.0025 \\
\hline DAR & 0.161032 & 0.195332 & 0.811935 & 0.4210 \\
\hline $\begin{array}{ll}R O E \\
\text { STE }\end{array}$ & -1.305255 & 0.396547 & $\begin{array}{l}-3.291533 \\
120097\end{array}$ & 0.0019 \\
\hline SIZE & -0.000674 & 0.005718 & -1.290997 & 0.2032 \\
\hline $\mathrm{CR}$ & -0.000425 & 0.011455 & -0.037151 & 0.9705 \\
\hline & \multicolumn{2}{|c|}{ Entects Specifcation } & S.D. & Fino \\
\hline $\begin{array}{l}\text { Cross-section random } \\
\text { ldosyncratic random }\end{array}$ & & & $\begin{array}{l}0.000000 \\
0.197972 \\
\end{array}$ & $\begin{array}{l}0.0000 \\
1.0000 \\
\end{array}$ \\
\hline \multicolumn{5}{|c|}{ Weigmed statstics } \\
\hline $\begin{array}{l}\text { R-squared } \\
\text { Adjusted R-squared } \\
\text { S.E. of regresslon } \\
\text { F-statstic } \\
\text { Prob(F-statstc) } \\
\end{array}$ & $\begin{array}{l}0.214733 \\
0.145449 \\
0.205125 \\
3.140599 \\
0.022851 \\
\end{array}$ & \multicolumn{2}{|l|}{$\begin{array}{l}\text { Mean dependemt var } \\
\text { S.D. dependemt var } \\
\text { Sum squared resid } \\
\text { Durbin-Watson stat }\end{array}$} & $\begin{array}{l}0.297451 \\
0.222026 \\
1.935502 \\
1.530239\end{array}$ \\
\hline \multicolumn{5}{|c|}{ Unwelgmed statstics } \\
\hline $\begin{array}{l}\text { R-6quared } \\
\text { Sum squared resid }\end{array}$ & $\begin{array}{l}0.214733 \\
1.935502\end{array}$ & \multicolumn{2}{|l|}{$\begin{array}{l}\text { Mean dependent var } \\
\text { Durbin-Watson stat }\end{array}$} & $\begin{array}{l}0.297451 \\
1.530239\end{array}$ \\
\hline \multicolumn{5}{|c|}{$\begin{array}{l}\text { Redundant Fixed Emacts Tests } \\
\text { Equaton: ECO1 } \\
\text { Test cross-6ecton fxed etracts }\end{array}$} \\
\hline Enects Test & & Statstc & dif. & Prob. \\
\hline $\begin{array}{l}\text { Cross-6ection } F \\
\text { Cross-section Cnl-square }\end{array}$ & & $\begin{array}{r}1.211511 \\
25.420050\end{array}$ & $(16,30)$ & $\begin{array}{l}0.3149 \\
0.0628\end{array}$ \\
\hline
\end{tabular}

Sumber : Hasil olahan eviews 0.9, 2020

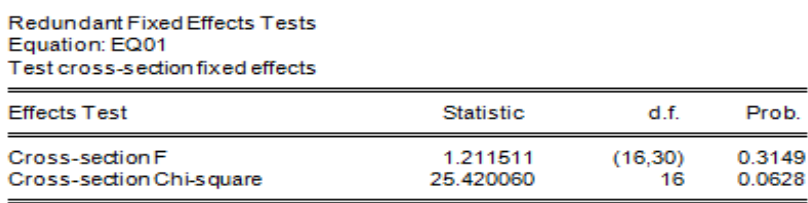

Cross-section fixed effects test equation:

Cross-section fixed effects
Dependent Variable: TAV

Method: Panel Least Squares

Date: 11/23/20 Time: 02:37

Sample: 20172019

Cross-sections included: 17

Total panel (balanced) observations: 51

Sumber : Hasil olah data eviews 9.0, 2020

Dari tabel hasil Uji Chow diatas menunjukan nilai cross-section $f$ dan cross-section chi-square $>$ a $(0,05)$ maka dapat disimpulkan bahwa Common Effect Model (CEM) lebih layak di gunakan dibanding Fixed Effect Model (FEM). 


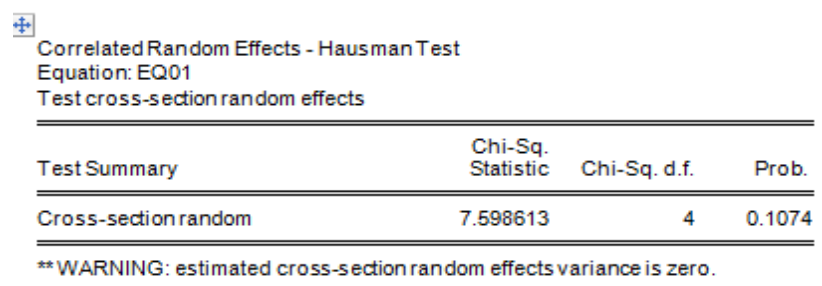

Sumber : Hasil olah data eviews 9.0, 2020

Pada hasil perhitunagn Uji Hausman diatas menunjukan bahwa nilai Probabilitas (Prob.) Cross-section random $>\alpha$ (0.05), yaitu 0.1074 yang artinya Random Effect Model (REM) lebih layak digunakan dibandingkan Fix Effect Model (FEM).

\begin{tabular}{l} 
Lagrange Multiplier Tests forRandom Effects \\
Null hypotheses: No effects \\
$\begin{array}{l}\text { Alternative hypotheses: Two-sided (Breusch-Pagan) and one-sided } \\
\text { (all others) alternatives }\end{array}$ \\
\hline \hline \multicolumn{4}{c}{ Test Hypothesis } \\
$\qquad$\begin{tabular}{llll} 
Cross-section & Time & Both \\
\hline \hline Breusch-Pagan & 0.539095 & $6.19 \mathrm{E}-05$ & 0.539156 \\
$(0.4628)$ & $(0.9937)$ & $(0.4628)$
\end{tabular}
\end{tabular}

Sumber : Hasil olah data eviews 9.0, 2020

Pada tabel perhitungan di atas menunjukan bahwa nilai Probabilitas Cross-Section Breaus-pagan< a $(0.05)$ yaitu $(0,4628)$ yang artinya model Common Effect Model (CEM) lebih layak di gunakan di banding Random Effect Model (REM).

Kesimpulan model regresi yang digunakan:

\begin{tabular}{|l|l|c|c|}
\hline NO & \multicolumn{1}{|c|}{ METODE } & PENGUJIAN & HASIL \\
\hline 1 & UII CHOW & CEM VS FEM & CEM \\
\hline 2 & UJ I HAUSMAN & FEM VS REM & REM \\
\hline 3 & UJ LANHGRANGE MULTIPLIER & CEM VS REM & CEM \\
\hline
\end{tabular}

Menurut Basuki dan Prawoto (2016) secara formal ada tiga prosedur pengujian estimasi data panel, yaitu uji Statistik $F$ yang digunakan untuk memilih antara :

1. Model Common Effect atau Fixed Effect

2. Uji Langrange Multiplier (LM) yang digunakan untuk memilih antara model common effect atau model random effect

3. Uji Hausman yang digunakan untuk memilih antara model fixed effect atau model random effects.

Berdasarkan Hasil pengujian yang sudah dilakukan diketahui bahwa pada Uji Chow yang terpilih model CEM dengan nilai cross-section f sebesar 0,3149 lebih besar dari 0,05 dan pada Uji Hausman model yang terpilih 
adalah estimasi model REM dengan nilai cross- section random sebesar 0.1074 lebih besar dari 0,05. Dan Uji Langrange Multiplier model yang terpilih REM dengan nilai Breusch-Pagan 0,4628 lebih besar dari 0,05.

Pengujian ini dilakukan untuk mengetahui pengaruh variabel independen, yaitu, Leverage, Profitabilitas,Ukuran perusahaan dan likuiditas terhadap variabel dependen yaitu Tax Avoidance. Untuk menguji signifikan pengaruh variabel-variabel independen $(X)$ terhadap variable baik secara parsial maupun bersama- sama (Eksandy dan Heriyanto, 2017:52). Adapun tahap pengujian dalam penelitian ini adalah sebagai berikut :

Uji kelayakan model atau biasa dikenal dengan Uji $F$ digunakan untuk menjelaskan apakah semua variabel bebas yang dimasukkan ke dalam model secara bersama-sama mempunyai pengaruh terhadap variabel terikat. Apabila Uji F tidak berpengaruh maka penelitian tidak layak untuk dilanjutkan karena mode penelitian tidak mampu menjelaskan adanya hubungan antara variabel independen dengan dependen. Bisa juga hal ini terjadi karena adanya hubungan antar variabel independen (Multikolinearitas) sehingga menyebabkan model penelitian menjadi tidak sehat (fit). Uji ini dapat dilihat dengan Hipotesis sebagai berikut :

a. Berdasarkan perbandingan F-Statistic dengan $\mathrm{F}$ table

$\mathrm{HO}$ : Jika nilai F-Statistic $<\mathrm{F}$ Tabel $\mathrm{Ha}$

: Jika nilai F-Statistic $>$ F Tabel

Jika F-Statistik < F Tabel, maka HO diterima yang artinya variabel independen $(X)$ secara bersama-sama tidak berpengaruh terhadap variabel dependen (Y). Namun sebaliknya, jika F- Statistik > F Tabel, maka Ha diterima artinya variabel independen $(X)$ secara bersama-sama berpengaruh terhadap variabel dependen (Y).

b. Berdasrkan probabilitas

$\mathrm{HO}$ : Jika nilai Prob (F-Statistic) $>\alpha 0,05$

$\mathrm{Ha}$ : Jika nilai Prob (F-Statistic) $<\alpha 0,05$

Jika Prob (F-Statistic) > a 0,05, maka HO diterima yang artinya variabel independen (X) secara bersama-sama tidak berpengaruh terhadap variabel dependen (Y). Namun sebaliknya, Jika Prob (F-Statistic) $<\alpha$ 0,05, maka Ha diterima artinya variabel independen (X) secara bersama- sama berpengaruh terhadap variabel dependen $(\mathrm{Y})$.

\begin{tabular}{crlrl} 
Berikut _... & adalah & \multicolumn{1}{c}{ hasil perhitungan } & uji & F \\
\cline { 1 - 3 } R-squared & 0.214733 & Mean dependent var & 0.297451 \\
Adjusted R-squared & 0.146449 & S.D. dependentvar & 0.222026 \\
S.E. of regression & 0.205125 & Akaike info criterion & -0.237504 \\
Sum squared resid & 1.935502 & Schwarzcriterion & -0.048109 \\
Log likelihood & 11.05634 & Hannan-Quinn criter. & -0.165130 \\
F-statistic & 3.144699 & Durbin-Watson stat & 1.530239 \\
Prob(F-statistic) & 0.022861 & & \\
\hline \hline
\end{tabular}


Sumber : hasil olah data eviews 9.0, 2020

Pada hasil uji F diatas menunjukkan bahwa nilai F-statistik sebesar 3.144699. variable bebas sebanyak 5 dan jumlah sampel adalah 51 . Maka DF1 (n1) $\mathrm{k}-1=5-1$ adalah 4 dan DF2 51-5=47. $\mathrm{F}$ tabel 2,80. Dengan demikian F-statistik (3.144699) > F Tabel $(2,80)$ dan nilai prob (F-Statistic) 0,022861 lebih kecil dari 0,05 maka dapat disimpulkan Ha diterima artinya variable independen $(X)$ secara bersama-sama berpengaruh terhadap variable dependen $(Y)$.

Hasil koefisien determinasi menjelaskan seberapa jauh kemampuan model regresi dalam menerangkan variasi variabel bebas mempengaruhi variabel terikat. Semakin besar hasil R-squared akan semakin baik karena hal ini mengidentifikasikan semakin baik variabel independen dalam menjelaskan variabel dependen. (Eksandy dan Heriyanto, 2017) Nilai R-squared berada antara 0 sampai 1 dengan penjelasan berikut :

a. Jika nilai R-squared sama dengan 1, berarti naik atau turunnya variable terikat $(Y)$ 100\% dipengaruhi oleh variable bebas $(X)$

b. Jika niali R-Squared sama dengan 0 , berarti tidak ada hubungan sama sekali anatar variable indepeneden terhadap variable.

\begin{tabular}{lrlr} 
Berikut & hasil adjusted & R-square \\
\hline \hline R-squared & 0.214733 & Mean dependent var & 0.297451 \\
Adjusted R-squared & 0.146449 & S.D. dependent var & 0.222026 \\
S.E. of regression & 0.205125 & Akaike info criterion & -0.237504 \\
Sum squared resid & 1.935502 & Schwarz criterion & -0.048109 \\
Log likelihood & 11.05634 & Hannan-Quinn criter. & -0.165130 \\
F-statistic & 3.144699 & Durbin-Watson stat & 1.530239 \\
Prob(F-statistic) & 0.022861 & & \\
\hline \hline
\end{tabular}

Sumber : hasil olah data eviews 9.0, 2020

Pada Tabel diatas menunjukkan nilai Adjusted R-Squared 0,146449 , artinya bahwa variasi perubahan naik turunnya TAV dapat di jelaskan oleh DER, ROA,SIZE dan CR sebesar 14,6 persen. Sementara sisanya yaitu sebesar 85,4 persen dijelaskan oleh variable - variable lain yang tidak diteliti dalam penelitian ini.

Hasil uji T menjelaskan signifikansi pengaruh variable bebas secara persial terhadap variable terikat. Hipotesis dalam uji t adalah sebagai berikut :

berdasarkan perbandingan t-statistic dengan t tabel :

$\mathrm{HO}$ : jika nilai t-statistic $<\mathrm{t}$ tabel

$\mathrm{Ha}$ : jika nilai t-statistic $>\mathrm{t}$ tabel

Jika nilai t-statistic < $\mathrm{T}$ tabel, maka $\mathrm{HO}$ diterima yang artinya variable independen $(X)$ secara persial tidak berpengaruh terhadap variable dependen $(Y)$. namun sebaliknya, jika nilai t-statistic $>$ disbanding $T$ tabel, 
maka Ha diterima yang artinya variable independen $(\mathrm{X})$ secara persial berpengaruh terhadap varaibel dependen $(\mathrm{Y})$

Berdasarkan probabilitas :

$\mathrm{HO}$ : jika nilai prob. $>$ a 0.05

$\mathrm{Ha}:$ jika nilai prob. $<\alpha 0.05$

Jika nilai prob. > a 0.05 , maka HO diterima yang artinya variable independen $(\mathrm{X})$ secara persial tidak berpengaruh terhdap variable dependen $(Y)$. namun sebaliknya jika nilai prob. < a 0.05, maka $\mathrm{Ha}$ diterima yang artinya variable independen $(X)$ secara persial berpengaruh terhdapa variable dependen $(\mathrm{Y})$.

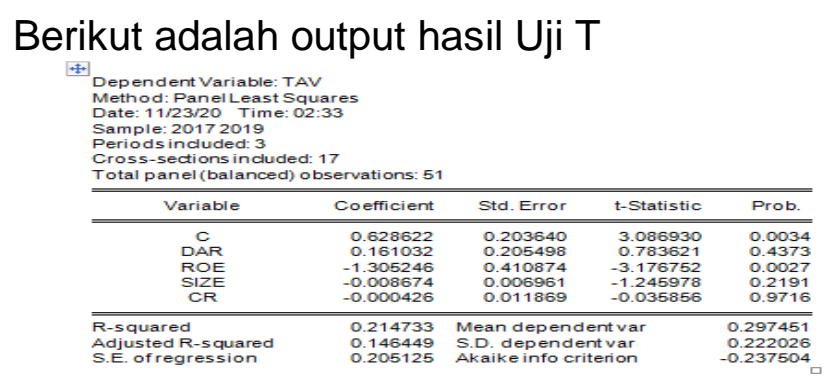

Sumber : hasil olah data eviews 9,0, 2020

Berdasarkan analisis regresi data panel yang dilakukan, maka hipotesis yang dihasilkan adalah sebagai berikut :

\section{Pengaruh ukuran perusahaan terhadap tax avoidance}

Nilai t statistic leverage adalah 3.086930, sementara t Tabel dengan tingkat $\alpha=5 \%$, df $(n-k)=47$ didapat nilai t Tabel sebesar 1,67793 dengan demikian t-statistic SIZE (3.086930) >t Tabel $(1,67793)$ dan nilai probabilitas $0.0034<0.05$. Maka dapat disimpulkan bahwa variable leverage (DAR) dalam penelitian ini memiliki pengrauh terhadap variable dependen yaitu tax avoidance. Dengan demikian $\mathrm{H} 1$ diterima, penelitian ini sejalan dengan penelitian sebelumnya Ni Koming Ayu Praditasari, Putu Ery Setiawan (2017) Leverage berpengaruh positif pada Tax Avoidance

\section{Pengaruh profitabilitas terhadap tax avoidance}

Nilai t statistic profitabilitas adalah 3.176752, sementara t Tabel dengan tingkat $\alpha=5 \%$, df $(n-k)=47$ didapat nilai t Tabel sebesar 1,67793 dengan demikian t-statistic ROA (3.176752) >t Tabel $(1,67793)$ dan nilai probabilitas $0.0027<0.05$.Maka dapat disimpulkan bahwa variable Leverage ( $R O A$ ) dalam penelitian ini memiliki pengaruh terhadap variable dependen yaitu tax avoidance. Dengan demikian $\mathrm{H} 2$ ditrima, penelitian ini sejalan dengan penelitian Menurut Ida Ayu Rosa Dewinta, 
Putu Ery Setiawan (2016), Profitabilitas berpengaruh positif terhadap Tax Avoidance

\section{Pengaruh ukuran perusahaan terhadap Tax avoidance}

Nilai t statistic ukuran perusahaan adalah 1.245978, sementara t Tabel dengan tingkat $\alpha=5 \%$, df $(n-k)=47$ didapat nilai t Tabel sebesar 1,67793 dengan demikian t-statistic ROE $(1.245978)<$ t Tabel $(1,67793)$ dan nilai probabilitas 0.2191> 0.05.Maka dapat disimpulkan bahwa variable ukuran perusahaan (SIZE) dalam penelitian tidak memiliki pengrauh terhadap variable dependen yaitu tax avoidance.Penelitian ini sejalan dengan penelitian sebelimnya (Ni Koming Ayu Praditasari, Putu Ery Setiawan,(2017)Ukuran perusahaan tidak berpengaruh terhadap penghindaran pajak (tax avoidance).

\section{Pengaruh likuiditas terhadap tax avoidance}

Nilai t statistic kepemilikan isntitusional adalah 0.035856 , sementara $t$ Tabel dengan tingkat $\alpha=5 \%$, df $(n-k)=47$ didapat nilai $t$ Tabel sebesar 1,67793 dengan demikian t-statistic CR $(0.035856)<t$ Tabel $(1,67793)$ dan nilai probabilitas $0.9716>0.05$.

Maka dapat disimpulkan bahwa variable likuiditas (CR) dalam penelitian ini tidak memiliki pengaruh terhadap variable dependen yaitu tax avoidance. Dengan demikian $\mathrm{H} 4$ ditolak, penelitian ini sejalan dengan penelitian Menurut Fitri Damayanti, Tridahus Susanto (2015) kepemilikan institusional tidak berpengaruh terhadap penghindaran pajak (tax avoidance).

\section{KESIMPULAN}

Penelitian ini memiliki tujuan untuk mengetahui pengaruh leverage,profitabilitas ukuran perushaan, dan likuiditas terhadap tax avoidance pada perusahaan makanan dan minuman yang terdaftar di Bursa Efek Indonesia selama periode 2016-2019. Sampel penelitian ini dipilih dengan menggunakan purposive sampling dan diperoleh data sebanyak 51 perusahaan dengan pertahunnya yaitu 17 perusahaan.

Berdasarkan data yang dikumpulkan dari hasil pengujian yang telah dilakukan dengan menggunakan uji analisis data panel , maka dari lima hipotesis yang diajukan dapat diambil beberapa kesimpulan, yaitu :

1. Hasil pengujian Hipotesis 1 membuktikan bahwa variable leverage (DAR) berpengaruh terhadap variable Tax Avoidance.

2. Hasil pengujian Hipotesis 2 membuktikan bahwa variable Profitabilitas (ROA) berpengaruh terhadap variable Tax Avoidance.

3. Hasil pengujian Hipotesis 3 membuktikan bahwa variable Ukuran perusahaan (SIZE) tidak berpengaruh terhadap variable Tax Avoidance.

4. Hasil pengujian Hipotesis 4 membuktikan bahwa variable likuiditas (CR ) tidak berpengaruh terhadap variable Tax Avoidance. 


\section{DAFTAR PUSTAKA}

Butje, S., \& Tjondro, E. (2014). Pengaruh Karakter Eksekutif Dan Koneksi Politik Terhadap Tax Avoidance. Tax \& Accounting Review, 4(2), 19. https://doi.org/10.1186/s40543-0140024-3

Swingly, C., \& Sukartha, I. (2015). Pengaruh Karakter Eksekutif, Komite Audit, Ukuran Perusahaan, Leverage Dan Sales Growth Pada Tax Avoidance. E-Jurnal Akuntansi, 10(1), 47-62.

Luh, N., \& Puspita, P. (2017). Pengaruh Ukuran Perusahaan, Leverage, Profitabilitas dan Corporate Social Responsibility Terhadap Penghindaran Pajak (Tax Avoidance). E-Jurnal Akuntansi, 21, 882911. https://doi.org/10.24843/EJA.2017.v 21.i02.p01

Maharani, I., \& Suardana, K. (2014). Pengaruh Corporate Governance, Profitabilitas, Dan Karakteristik Eksekutif Pada Tax Avoidance Perusahaan Manufaktur. E-Jurnal Akuntansi, 9(2), 525-539.

Hakim, M. Z., \& Naelufar, Y. (2020). Analysis of Profit Growth, Profitability, Capital Structure, Liquidity and Company Size of Profit Quality. $\begin{array}{llll}\text { Jurnal Akademi } & \text { Akuntansi, } & \end{array}$ https://doi.org/10.22219/jaa.v3i1.1 0348

Damayanti, F., \& Susanto, T. (2016). Pengaruh Komite Audit, Kualitas Audit, Kepemilikan Institusional, Risiko Perusahaan Dan Return on Assets Terhadap Tax Avoidance. Esensi, 5(2), 187-206. https://doi.org/10.15408/ess.v5i2.2 341

Khairunisa, K., Hapsari, D. W., \& Aminah, W. (2017). Kualitas Audit, Corporate Social Responsibility, Dan Ukuran Perusahaan Terhadap Tax Avoidance. Jrak, 9(1), 39. https://doi.org/10.23969/jrak.v9i1.3 66

Wiatr-Kmieciak, M. (2016). „Просто Наступила Зима” - Повторительный Урок Для Раздела 1 (Времена Года) Учебника „Вот И Мы 2”. Studia Rossica Posnaniensia, 40(1), 285-292. https://doi.org/10.14746/strp.2015. 40.1.28

Hidayat, W. W. (2018). Pengaruh Profitabilitas, Leverage Dan Pertumbuhan Penjualan Terhadap Penghindaran Pajak. Jurnal Riset Manajemen Dan Bisnis (JRMB) Fakultas Ekonomi UNIAT, 3(1), 1926. https://doi.org/10.36226/jrmb.v3i1. 82

Oliver, J. (2019). 済無 No Title No Title. Hilos Tensados, 1, 1-476. https://doi.org/10.1017/CBO97811 07415324.004

Barjono, \& Hakim, M. Z. (2018). Pengaruh Ukuran Perusahaan, Profitabilitas, Solvabilitas, Opini

Audit, dan Kualitas Auditor terhadap Audit Delay pada Perusahaan Tambang Batubara yang Terdaftar di BEI Periode 2012-2016. Jurnal Akuntansi, 1-10.

Oktamawati, M. (2017). Pengaruh Karakter Eksekutif, Komite Audit, Ukuran Perusahaan, Leverage, Pertumbuhan Penjualan, Dan Profitabilitas Terhadap Tax Avoidance. Jurnal Akuntansi Bisnis, 15(1), 23-40. https://doi.org/10.24167/JAB.V15I1 .1349 
Maharani, I., \& Suardana, K. (2014). Pengaruh Corporate Governance, Profitabilitas, Dan Karakteristik Eksekutif Pada Tax Avoidance Perusahaan Manufaktur. E-Jurnal Akuntansi, 9(2), 525-539.

Hakim, M. Z., \& Naelufar, Y. (2020). Analysis of Profit Growth, Profitability, Capital Structure, Liquidity and Company Size of Profit Quality. $\begin{array}{llll}\text { Jurnal Akademi } & \text { Akuntansi, }\end{array}$ https://doi.org/10.22219/jaa.v3i1.1 0348

Damayanti, F., \& Susanto, T. (2016). Pengaruh Komite Audit, Kualitas Audit, Kepemilikan Institusional, Risiko Perusahaan Dan Return on Assets Terhadap Tax Avoidance. Esensi, 5(2), 187-206. https://doi.org/10.15408/ess.v5i2.2 341

Khairunisa, K., Hapsari, D. W., \& Aminah, W. (2017). Kualitas Audit,

Corporate Social Responsibility, Dan Ukuran Perusahaan Terhadap Tax Avoidance. Jrak, 9(1), 39. https://doi.org/10.23969/jrak.v9i1.366

Wiatr-Kmieciak, M. (2016). „Просто Наступила Зима” - Повторительный Урок Для Раздела 1 (Времена Года) Учебника „Вот И Мы 2”. Studia Rossica Posnaniensia, 40(1), 285-292. https://doi.org/10.14746/strp.2015. 40.1.28

Hidayat, W. W. (2018). Pengaruh Profitabilitas, Leverage Dan Pertumbuhan Penjualan Terhadap Penghindaran Pajak. Jurnal Riset Manajemen Dan Bisnis (JRMB) Fakultas Ekonomi UNIAT, 3(1), 1926. https://doi.org/10.36226/jrmb.v3i1. 82

Oliver, J. (2019). 済無 No Title No Title. Hilos Tensados, 1, 1-476. https://doi.org/10.1017/CBO97811 07415324.004

Barjono, \& Hakim, M. Z. (2018). Pengaruh Ukuran Perusahaan, Profitabilitas, Solvabilitas, Opini Audit, dan Kualitas Auditor terhadap Audit Delay pada Perusahaan Tambang Batubara yang Terdaftar di BEI Periode 2012-2016. Jurnal Akuntansi, 1-10. 